\title{
Ever-Lockdown: Waiting through Times of Playbour and Pandemic in Animal Crossing
}

\author{
MERLIN SELLER, University of Edinburgh
}

\begin{abstract}
Animal Crossing: New Horizons' (Nintendo 2020) huge popularity has previously been attributed to escapism prompted by the singularity of lockdown life (Frushtick 2020; Zhu 2020), resonating with analyses which have been quick to frame lockdown as a radical historical caesura in experiences of work and leisure (Harari 2020; Krastev 2020). However, Chmielewski and Bruno argue that lockdown can be seen in relation to continuities in neoliberalism's alienation, isolation and hyperconnected domestic digital labour (Chmielewski 2020; Bruno 2020) — a condition of prolonged and displaced anxiety I term 'ever-lockdown' necessitating a more nuanced account of Animal Crossing's ambivalent mix of busywork and relaxation. Rather than escapist utopia, consumerist dystopia (Chang 2019), or softened capitalism (Bogost 2020), I will consider Animal-Crossing as providing absorbing boredom in which intense interactivity can be interpassively (Pfaller 2017) withheld in a time of demanding and destabilising crises, facilitating a subtle, affective sense of place amidst the 'everlockdown.'
\end{abstract}

\section{KEYWORDS}

Lockdown, Animal Crossing, playbour, interpassivity, games

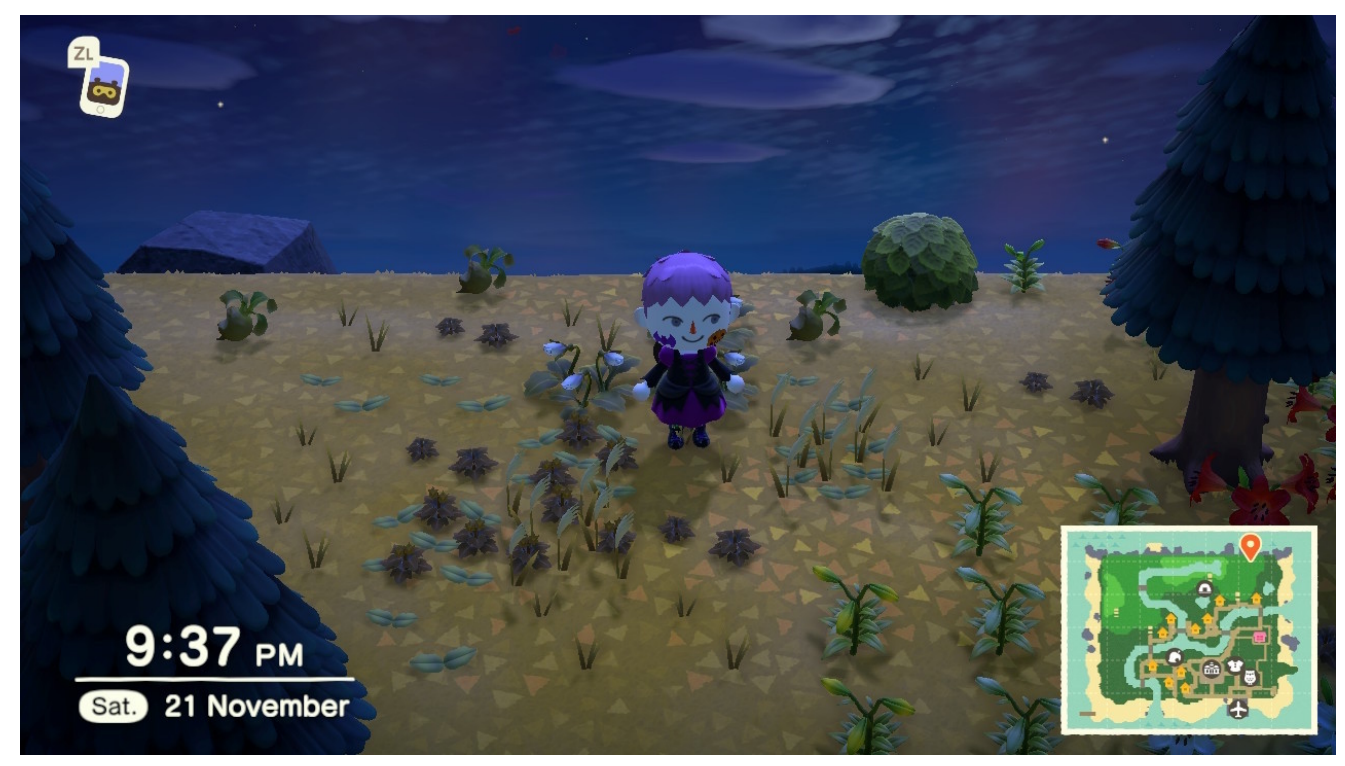

Figure 1: Weeds in Animal Crossing: New Horizons (Nintendo 2020) [Author's screenshot] 
Weeds, weeds, weeds: This was my reckoning as a lapsed but repeat player of Animal Crossing: New Horizons (Nintendo,2020), and a familiar scene for returning players [Fig. 1]. It's the shadow of regular play-the daily check-in with the slow-life of repose in an island community-regular rhythms, charming greetings, the appreciation of seasonal shifts. Working, weeding and walking — or refusing all the above — the player finds themselves flirting with boredom, anxiety and interpassivity in ways which resonate with our experience of national lockdowns and resist easy explanation. Neither utopian nor dystopian, leisure nor labour, I here argue that this game provides a 'topian' (Olwig 2002) sense of place reflecting on the absurd negations and continuities of life alongside COVID.

Animal Crossing: New Horizons (hereafter $A C N H$ ) — at first glance kitsch and escapist, on second appraisal mercurial and capitalist - is a game of contradictions. As Bogost reflects on the origins of the series, ${ }^{1}$ the game exists in tension between consumption and ecology (2007), but more recent entries are further suspended between slowness and acquisitiveness (ScullyBlaker 2019), escapist play (Zhu 2020) and a serious "political hypothesis" of a future sphere of labour without losers (Bogost 2020). Moreover, the game has enjoyed huge sales success (Batchelor 2020) while offering limited interactivity and, for good or ill, janky (unpredictable) controls (Schmalzer 2020). Harnessed to the slowness and restrictions of a real-time clock it provides play, which, like post-industrial work we cannot completely "turn off” (Scully-Blaker 2019, 97).

Through this case study, this paper addresses experiential continuities under lockdown-a protracted process of alienation, anxiety and isolation at the intersection of domestic play and work which I term the state of 'ever-lockdown.' Here I combine direct analysis with elements of paratextual discourse analysis, supported by theory, to make an argument based on reading this case study and the synthesis of existing scholarship to see $A C N H$ in context. Through textual analysis of this game in relation to quotidian activities, I suggest that $A C N H$ provides the player with a place in which to dwell and exorcise negative affects while ambivalently resisting the creep of neoliberalism through boredom and interpassivity. Following an extended literature review of work on our current socioeconomic moment and the discourse surrounding the game text, I elaborate my analysis in three moments of single-player experience- the ambiguous atmospherics of 'playbour,' the player's subtle affective relationship to weeds, and the potentials of 'waiting' and 'dwelling' as a mode of affective resistance. I argue that rather than a utopian escape from pandemic reality, or a dystopian capitulation to Capitalism, this game facilitates a complex and subtle affective response to longer-term conditions of alienation and playbour through a quotidian sense of 'place' (Ingold 2010, Olwig 2002, Solnit 2002).

\section{‘Ever-lockdown' and Animal Crossing}

While recent analyses (Harari 2020; Krastev 2020; Žižek, 2020) and popular discourse (Dartnell 2020; Tisdall 2020) have been quick to frame lockdown as a radical historical caesura in (privileged Western) experiences of work and leisure, McCormick frames the social

\footnotetext{
${ }^{1}$ Mechanically similar prequels were released 2001-2017 with equivalent core game loops, my interest lies in $\mathrm{ACNH}$ for the contemporary cultural context in which it emerges, and the graphical advances that afford a sense of place to a greater degree than graphically simpler releases: soft, tactile textures and detailed animation such as the wind blowing through the trees.
} 
experience of COVID as one of 'indefinite liminality' (2020). Despite nationalist rhetoric suggesting phases, conclusions and 'battles', COVID resists definitive narratives and categorical distinctions. Bruno has recently argued that the post-COVID form of neoliberal biopower we are experiencing across the West is actually an acceleration of hyperconnected domestic space, rather than a radical departure (2020). As Soderman notes, using the work of Hochschild (2001), the blurring of boundaries between work and home exposes the already pressing political issues of time and space, which only become more evident during lockdown (Soderman 2017, 53). This fits a pattern of longer and more irregular working hours in recent years (Johnson \& Libscomb 2006) and the chronic issue of anxiety disorders which have doubled among young people between 2007-2018 (Duffy et al. 2019) and only been exacerbated during the COVID-19 epidemic (Twenge \& Joiner 2020). Work, leisure, public spheres, private spheres, sociality and isolation are all anxiously fused in homes which act as sites of labour, care and play_-but for our increasingly immaterial labour, our 'bullshit jobs' (Graeber 2018) and networked social lives, we can see this as representing continuity rather than a radical break: a condition I term 'ever-lockdown.'

Before the pandemic, argues Chmielewski, we (in the privileged West) already lived in heavily abstract, distanced societies of urban isolation and alienation-what has been lost in the pandemic is 'only' the last sliver of notional contact in our increasingly impoverished and heavily mediated social lives $(2020,377)$. Indeed, even Žižek, in discussing the potential for radical post-pandemic futures suggested by state interventionism, opens and concludes his book Pan(dem)ic! with poignant continuities in labour: the fact that most blue-collar jobs continue regardless of risk especially outside of the privileged West (2020, 17-29); and that those who fear the pandemic most are those of us whose lives have changed the least (2020, 107-114). Already working from home renders the threat intangible and, without visible markers of change in our everyday routines, the subject of exponential fantasy. As Žižek reflects on his own life, referencing a Lubitsch joke: 'Prior to the crisis, it was an isolation "without milk"- I could have gone out, I just chose not to. Now it's just the plain coffee of isolation with no possible negation implied' (Žižek 2020, 108). What COVID highlights, therefore, is that we were already in a form of alienated neoliberal lockdown. Protesting a loss of 'authentic' contact in our current Zoom/Teams lives can thus be seen as a displaced mourning of the fact that many of us were already largely working and playing digitally in a fourth industrial revolution which has already been 'blurring the line between the physical, digital and biological spheres' (Schwab 2016, n.p.).

Digital Humanities work attests to the commodification and mediation of vast swathes of our social lives and interactions (Kingwell 2019), a condition of surveillance capitalism which seeks to maximise the productive potential of every moment through technological interfaces in all manner of work and domestic spaces (Moore et al. 2018). The rise of networked technologies has for years also been logistically shifting economies of attention from public venues of production and entertainment to the living room and digital devices - phones, computers, consoles, VR, speakers and TVs have all already turned domestic space inside-out (Snickars \& Vonderau 2009; Fleury et al. 2020); and Kücklich, Boellstorff and Taylor have shown that games have a history of combining work and play in increasingly complex and pervasive game worlds (Kücklich 2005; Boellstorff 2013; Taylor 2018). The folk taxon of the infinitely playable 'ever-game' (Bowman 2019, 155-6) thus grows to meet the long trajectory 
of the 'ever-lockdown.'

In this context, the meteoric success of Animal Crossing's slow, task-driven busywork presents itself as an intriguing space of play and labour, analogous to 'playbour' (Kücklich 2005), articulating a living-room-office always already in lockdown. Here, while player efforts are not directly co-opted as game development, player engagement with $A C N H$ 's has fed into hosted virtual marketing strategies, streaming culture, the aftermarket for assets sold between players and representationally its internal economy and repetitious loops are a salient example of how leisure has incorporated work from in-game mortgage payment to $A C N H$ 's fictive phone apps (the surveillance-capitalist device de jour). Indeed, $A C N H$ is a platform for corporate advertising campaigns and brand-tie-ins aimed at replicating physical experiential campaigns through multiplayer use of its islands (Liffreing 2020). As Kang et al. (2020) identify, a renewed white flight during COVID has also seen many affluent Americans move to work-from-home in the countryside, co-locating pastoral, domestic and labouring lives. Perhaps, then, we can see the virtual turn to the countryside village as a similar imaginative trajectory - not just an escape, but a change of dwelling, and with it a modulation of workfrom-home. Ian Bogost points the way to recognising some of the ambivalent and mundane nature of player desire here: 'Nobody really wants to live a pastoral-capitalist equilibrium of humdrum labour - unless that's what everyone wants, actually, and not even so secretly' (2020) — but does this attachment really point to a hopeful playbouring future as Bogost has it, or to our boring 'indefinite liminality?' Do we really stay for the Capitalism, or does this game speak in different ways to our 'ever-lockdown'?

Animal Crossing's popularity has been critically framed as a cure to lockdown's assumed 'cabin fever' (Frushtick 2020; MacDonald 2020; Zhu 2020). Enjoying huge commercial success following its release during lockdown on March 20, 2020, it topped the sales charts for the medium as a whole, selling 4 million copies in its first weeks of release in Japan alone (Batchelor 2020), and 26 million in total at the time of writing (Yeung 2020), enmeshing it in the global COVID economy. Yet this franchise has for much of existence remained a niche experience. To outsiders, particularly to the hegemonic masculine-coded hardcore gamer who demands challenge, risk and complex interactivity (Juul 2009; Chess 2017), ACNH is puzzling, uninteresting and even aggravating. As Lantz, director of the NYU Game Center describes $A C N H$ : 'It is the most boring, long-winded, repetitive, condescending, infantile bullshit we've ever seen' (2020 cited Bogost 2020). Yet while prima facie the game's promise of a tropical island to craft and share at your leisure might suggest its success stems from affording a pastoral retreat from quarantine reality (Frushtick 2020), I argue that explaining this games' sensational and counter-intuitive success needs to engage more deeply with its subtle affects. this evergreen 'ever-game' (Bowman 2019) of open play resonates strongly and strangely with the deep continuities of 'ever-lockdown' in which work and leisure have always already been co-located and hypermediated.

$A C N H$ situates the player as the community leader of a small, relaxing island of anthropomorphic animals, following diurnal rhythms tied to a real-time/real-world clock. With a simple control scheme and small pool of player verbs we spend as much time waiting as 'doing,' and thanks to the Switch platform's portability it can readily function as an example of what Keogh and Richardson term the 'background' or 'ambient' game (2018). Our principal activities in $A C N H$ are gradual and piecemeal-collection, commerce, crafting and 
conversation - everything can be sold, but with minimal pressure for us to buy anything what becomes more of a goal in this largely goalless game is the emotional satisfaction of our community and ourselves through discourse, decoration and the donation of specimens to our local museum. This is a game visually characterised by soft pastel colours and velveteen textures, unfurling for us like a scroll with the dramatic curvature of a horizon that yields steady, soft surprises.

However, the pressures of real-time - a key political terrain in 'ever-lockdown' - enmeshes this gentle game with the compromises of surveillance capitalism. As Scully-Blaker observes: '[in] an interesting reversal of the idea that one can never quite 'turn off' from their working life [...] one is altogether incapable of 'turning off' the game's monitoring of their play' (2019, 97). The ambient weight of our island dwelling's mortgage, and the clear exchange value of every object, leads Chang to argue that the game perpetuates thinly veiled 'logics of consumerism and capital accumulation' $(2019,70)$. Indeed, $A C N H$ 's overt fictive monetisation of player activity has even inspired its use as a humorous illustration of real-world median wages from the United States Bureau of Labor Statistics. But as Scully-Baker observes: '...Animal Crossing's capitalism is so overt that I would argue it operates against the player ever becoming some sort of cultural dupe' (Scully-Blaker 2019, 98). Indeed, as hinted at in my brief summary of the game, our island is as much a gift economy as a profit-driven one, with animals regularly sending us objects with the expectation of respectful reciprocity based on preferences not prices, to say nothing of the player's civic duties of benefaction through public works and museum acquisition.

If not a Capitalist simulacrum, what then does this space provide for the millions who now live there? Bogost identifies more complexity in the series which he characterises as an unresolved conflict between consumerism and ecological awareness (2007), and more recently as a playful amelioration of capitalist labour (2020). In the latter analysis, $A C N H$ gestures to a future with 'no losers,' in which all activity is monetarily rewarded, creating a world of small dreams and mundane activities that nonetheless allow the player to: 'Imagine if everyone had a job that they enjoyed, that they were good at, and that could sustain them' (Bogost 2020). More radically, this idea of play which sustains us through mundane rituals has been explored by Stone (2018) in terms of affect, citing Animal Crossing: New Leaf (Nintendo 2013) as articulating and potentially redressing Lauren Berlant's concept of 'slow death' $(2011,95)$ the forgettable, everyday but deeply important work of survival and maintenance in a mental/physical state of deterioration and being worn out. Indeed, if COVID draws our attention to slow death, what does $A C N H$ 's endlessly ticking model of playbour with 'no losers' - and perforce no winners - mean for our affective lives in ever-lockdown?

Rather than Zhu's escapist utopia, Chang's consumerist dystopia, or Bogost's softened capitalism, I read Animal Crossing as a usefully absorbing boredom in which intense interactivity can be happily withheld in a time of prolonged and intangible crisis. Through the procedural generation of tasks and their slow, boring but comforting elaboration (or equally possible rejection), Animal Crossing reflects on eerily familiar playbour with a meandering, flowering of processes and materials. By interpassively mediating and displacing work as something both boring and comforting $A C N H$ helps materialise the fuzzy alienation of the everlockdown through practices and entanglements of growing, caring and dwelling. 
$A C N H$ is a complex malleable single-player and multiplayer world that elapses over the course of months, and so to focus my analysis I will look at three areas of player (non)interactivity drawing on personal experience after several weeks of play: our relation to currency, plants and boredom, and perambulatory (non)actions of walking and waiting in the topian space between utopia and dystopia.

\section{Playbour and Atmosphere}

In order to firmly establish the groundwork of activity and affect in this game, we need to dig deeper into the subtle and ambiguous atmospherics of $A C N H$ 's work and play. Early on in their island life, players of $A C N H$ finds themselves in receipt of a fictive smartphone, and with it an endless litany of redeemable tasks - from planting flowers to picking mushrooms, all paid for in the currency of 'Nook Miles' which can be used to acquire goods, services and resources. $A C N H$ contains many dubious tasks from (im)balancing developed space and nature to increase your island's star rating to thematically restrained interior decoration aimed at increasing a 'Happy Home Academy' score that Bogost has argued ambivalently: 'attempts to persuade the player to understand both the intoxication of material acquisition and the subtle pleasures of abstention' (Bogost 2007, 275). However, as pure exchange value, Nook Miles encourage no such stoicism or balance. While the currency might reflect Bogost's dream where we 'Imagine if everyone had a job that they enjoyed, that they were good at, and that could sustain them' (2020), monetizing tasks such as taking a photo or planting a flower also resonate with Graeber's concept of the real-world 'bullshit job': 'It's as if someone were out there making up pointless jobs just for the sake of keeping us all working' (2018). As we build our islands to entertain our animals, ourselves and our friends, we engage in what Dyer-Witheford and de Peuter identify as the immaterial labour of intellectual and affective creation: 'a blurring of the boundaries between work and leisure, creating a continuum of productivity, and of exploitability,' (2009, 23) placing $A C N H$ in closer sympathy with our world of work than Huizinga's (1998) tired model of play's escapist magic circle. But is there really no unalienated space over the horizon, does the algorithm condemn us to work for work's sake?

With Jenkins' writing on gendered spaces of play and the decline of the childhood backyard (2006), we might see our island in relation to Victorian boys' adventure literature as a Robinson Crusoe narrative - but our work here is much more banal than adventurous, and a project of community empathy rather than individualist bourgeois domination. In terms of gender, then, $A C N H$ might more productively fit within the designed identity of 'Player 2' as Chess identifies in games of cleaning and affective labour targeted at women, never allowing the player uninhibited leisure (2017, 59-61). Indeed, $A C N H$ 's players engage in a range of affective labour that encompasses the diffusing of NPC arguments, celebration and gifting, and responses to passive aggressive comments in person and through the weight of automated in-game mail.

More compellingly than Jenkins' model of a 'boy's adventure,' in our tiny aesthetic projects and meditative busywork we might instead find affinity with Jenkins' assessment of Animal Crossing as a game of emotional encounters: 'an endless jolt of surprise or (if you will) a video game of player-generated secret attractions' (2007, n.p.). However, this too is not without its ambiguities. NPCs can make surprises as much as players - through decoration, behaviour, nicknames and seasonal events_-while the Nook Miles system also proceduralise the player's 
work of making 'secrets', leaving us with something between surprise and boredom, agency and passivity. What still applies from Jenkins' assessment of older Animal Crossings though, is an intriguing emphasis on the series' affordances of 'atmospheric manipulations' (2007, n.p.) - from gardening to terraforming - which evokes Bogost's contemporaneous interest in the game's relationship of 'material things to intangible sensations' (Bogost 2007, 274-5). This atmosphere, affectively connecting player mood to the finicky core creative mechanics of positioning objects in a landscape, can generate both mundane spaces of episodic work in a capitalist world (Stone 2018), as well as subversive spaces of jankiness and unintended consequence (Schmalzer 2020).

\section{Weeds and Subtle Affects}

These atmospherics tangle the player in a mix of subtle affects and sense of place: from the listlessness of repetition to the mild panic of lost time with the sight of a visually fictive but temporally real sunset over the horizon; from a breeze that makes the whole island shiver and tingle with delight to the comfort of gardening rituals that change with the seasons. While the popularity and pedigree of this game leads theorists to make dramatic claims for Animal Crossing's emancipatory or oppressive affordances, this is fundamentally a game of soft feelings and everyday activities. From sending and receiving letters with your animal friends to picking and pruning at a world of flora, this is also crucially an atmosphere at the periphery of the human and non-human world - and it is with weeds and weeding that we can see how $A C N H$ really reflects the subtle affective atmosphere of the 'ever-lockdown.'

In recent years there has been a growing literature on affect in games beyond immediate disciplinary concerns with 'immersion' and 'fun' (Perron and Schröter eds 2016; Isbister 2016) and here I use 'affect' in the feminist and queer theory, phenomenological and non-cognitivist sense of Anable's Playing with Feelings as the dynamic: "cultural expression of underrepresented feelings (2018, xviii). A common feeling of lapsed players is guilt at the expected morass of plant matter on their return (See Carpenter 2020) - fear that weeds will have taken over, as if their growth displaces us. Indeed, as Mabey writes of weeds in Western culture, they represent something unruly, unwanted and parasitic, however, he cautions us that in reality humans and weeds flourish together: 'Weeds thrive in the company of humans. They aren't parasites, because they can exist without us, but we are their natural ecological partners, the species alongside which they do best' $(2010,12)$. This co-flourishing is indeed possible in $A C N H$ where, unlike previous instalments in the series, the game passes no explicit negative judgement on the player who leaves their weeds alone [Fig. 1], and for some players weeds are beautiful and actively fostered (Parrish 2020). Weeds emblematise the ambivalence of a game Bogost rightly argues allows us to work hard or not at all (Bogost 2020), and as he notes, the plant motif of a nibbled leaf that identifies most game objects speaks to a fundamental ephemerality of things in Animal Crossing $(2007,272)$. We can sit and watch the weeds grow, spreading over the island, wafting gently in the wind, or we can prune to our heart's content, slowly, deliberately and repetitively stooping to pick up foliage and garden our world into bloom. We can even leave the game's equivalent of 'stocks' (turnips) to rot in the sun. Much as Scully-Blaker writes of a mode of engaging with Animal Crossing: Pocket Camp's general mechanics, there is space here for 'radical slowness' in a game series they argue is unusual in 
punishing you more for running than for idleness $(2019,96)$. As the historian Solnit reflects, slow pacing of the landscape has useful affordances in anxious times: 'I like walking because it is slow, and I suspect that the mind, like the feet, works at about three miles an hour. If this is so, then modern life is moving faster than the speed of thought, or thoughtfulness.' (2001, $18)$.

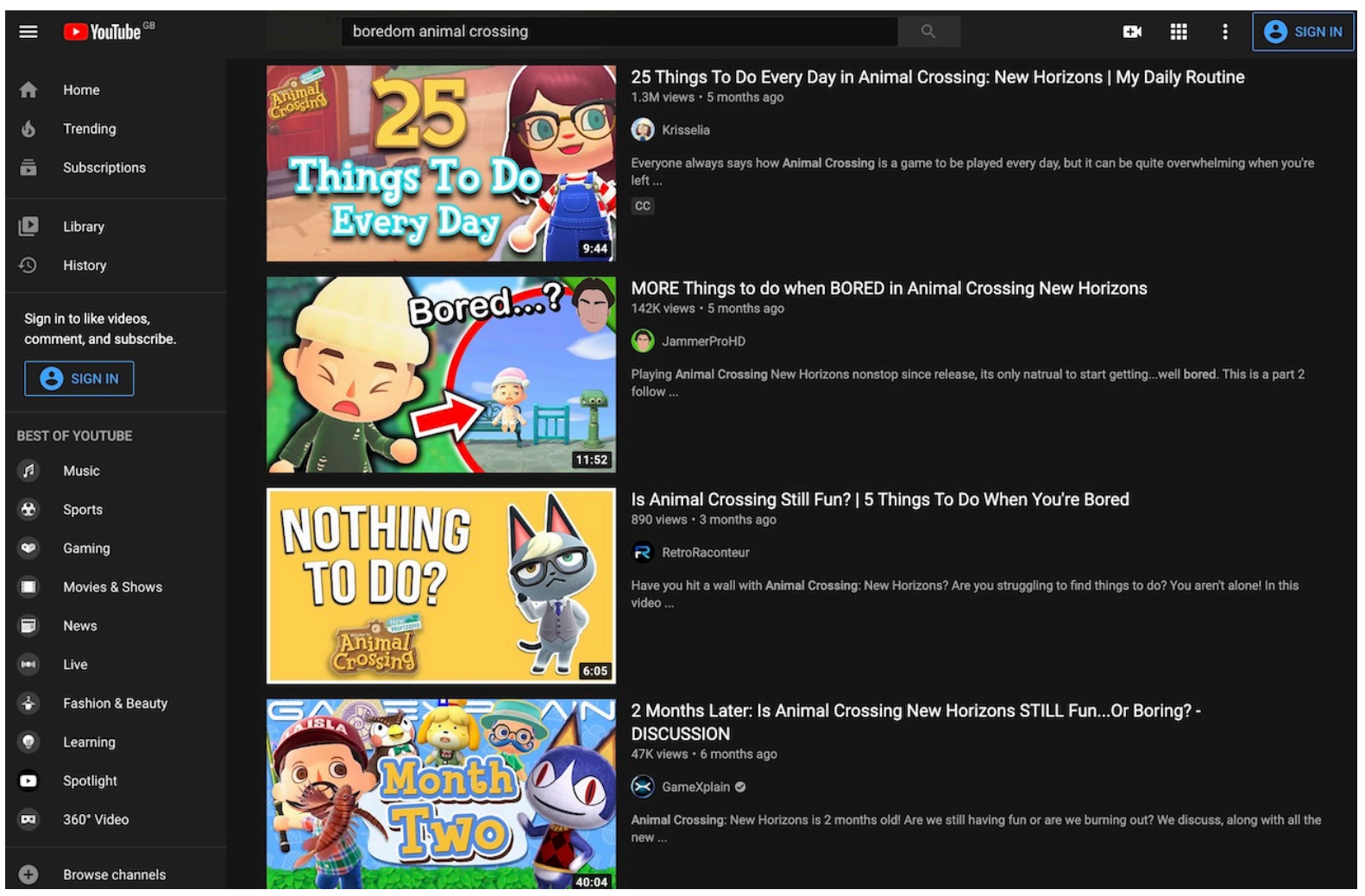

Figure 2: YouTube search indicative of fan discourse correlating boredom and Animal Crossing URL: https://www.youtube.com/results?search_query=animal+crossing+boredom [Accessed 23/11/2020]

Our actions in $A C N H$ often involve waiting and watching by default - our interventions are often minor notes, a soft touch: the shaking of trees, the slow and simple rhythms of bugcatching and fruit-picking which involve a careful eye, picking our risk-free moment. The monotony and endlessness of weeds and weeding, however, as magnified by the game's general atmospheric rhythms of repetition and repose, can leave the player with frequent moments of boredom. Interestingly, a simple YouTube search [Fig. 2] reveals $A C N H$ to be both a widespread source of and solution to boredom, and critical commentary highlight this unusual ambivalence: 'Animal Crossing: New Horizons Is an Escape Into Comforting Boredom' (Urquhart 2020); 'Animal Crossing Game Helps Cure Quarantine Boredom, Anxiety During Pandemic' (Chery 2020). ${ }^{2}$ There exists, then, a soft and intriguing tension between the boring monotony of island processes that push players away and the comforts and

\footnotetext{
2 It is worth noting in passing that the use of streaming platforms has accelerated during lockdown in a mode which has become habitual (Gupta and Singharia 2021). Though this is beyond the scope of this article, see Taylor (2018) and Gekker (2018) for more on the implications of streaming 'let's plays' etc. of games specifically.
} 
attractions this 'boring' regularity also affords.

Hand writes of digital boredom as an increasingly common condition in the West, an intensification brought about by Capitalism (Gardiner and Haladyn eds 2017). For Fisher, however, our digital lives give us reason to be nostalgic for boredom as a stable state of total absorption now denied us by neoliberalism's anxious state of perpetual distraction and displacement (2016, 688-90). In Fisher's account everything has become boring, but everyone is stimulated just enough by the compulsions of digital interactivity that they are never bored. Rather than the boring monotony of labour in the early $20^{\text {th }}$-century, work offers engagement and opportunity but is fundamentally characterised by precarity, disturbance and anxiety. As Meyrowitz has written of digital media: they offer us a world of possibility, but they can deprive us of the security afforded by a stable sense of place (1987).

Perhaps this explains the tension of $A C N H$ 's banality - its boredom is an attractive alternative to anxiety, an opportunity to be absorbed. Indeed, if ever-lockdown reflects an upward trend in anxiety rather than boredom, we should be attentive to whether games anxiously distract us or give us space to be bored. Soderman, analysing more intensive games of busywork, argues that games like Diner Dash seem to kill dead time - but for people with no time to be bored, all they offer is the substitution of anxiety with a more pleasurable form of anxiety (Soderman 2017). The embrace of boredom, then, becomes a subversive alternative to anxious distraction - it takes the form of waiting, of dwelling in a place that is both uncomfortable and resistant to anxious displacement in 'The modern world of people cast adrift, unanchored by the securities of place...' (Solnit 2001, 160).

As the philosopher of boredom Svendsen argues, processing affects takes the time that modernity deprives us of, making staying with boredom crucial: 'Nowadays, where efficiency is one of the great buzz words, we prefer everything to move at a brisk pace, but that is not how things are when it comes to processing that which deeply affects us. That must take time' (Svendsen 2005, 145-146). Wark might agree with Soderman that games replicate the conditions of neoliberalism rather than offering an alternative, to the extent that she sees our fraught lives as a fundamentally gamified 'gamespace': 'The utopian dream of liberating play from the game, of a pure play beyond the game, merely opened the way for the extension of gamespace into every aspect of everyday life' $(2007,16)$. Yet, in her analysis, boredom in play is a rupture with playbour, a source of resistance: 'Boredom lays waste to the appeal of the game as game, and calls attention to the ambiguous relation of game to gamespace.' (2007, 33). As such, boredom is subversive, an affect that points to a place outside of neoliberalism, and in the ever-lockdown boredom may just be the uncomfortable, strange horizon beyond which exists a less alienated world with time to feel.

\section{Waiting and Resisting}




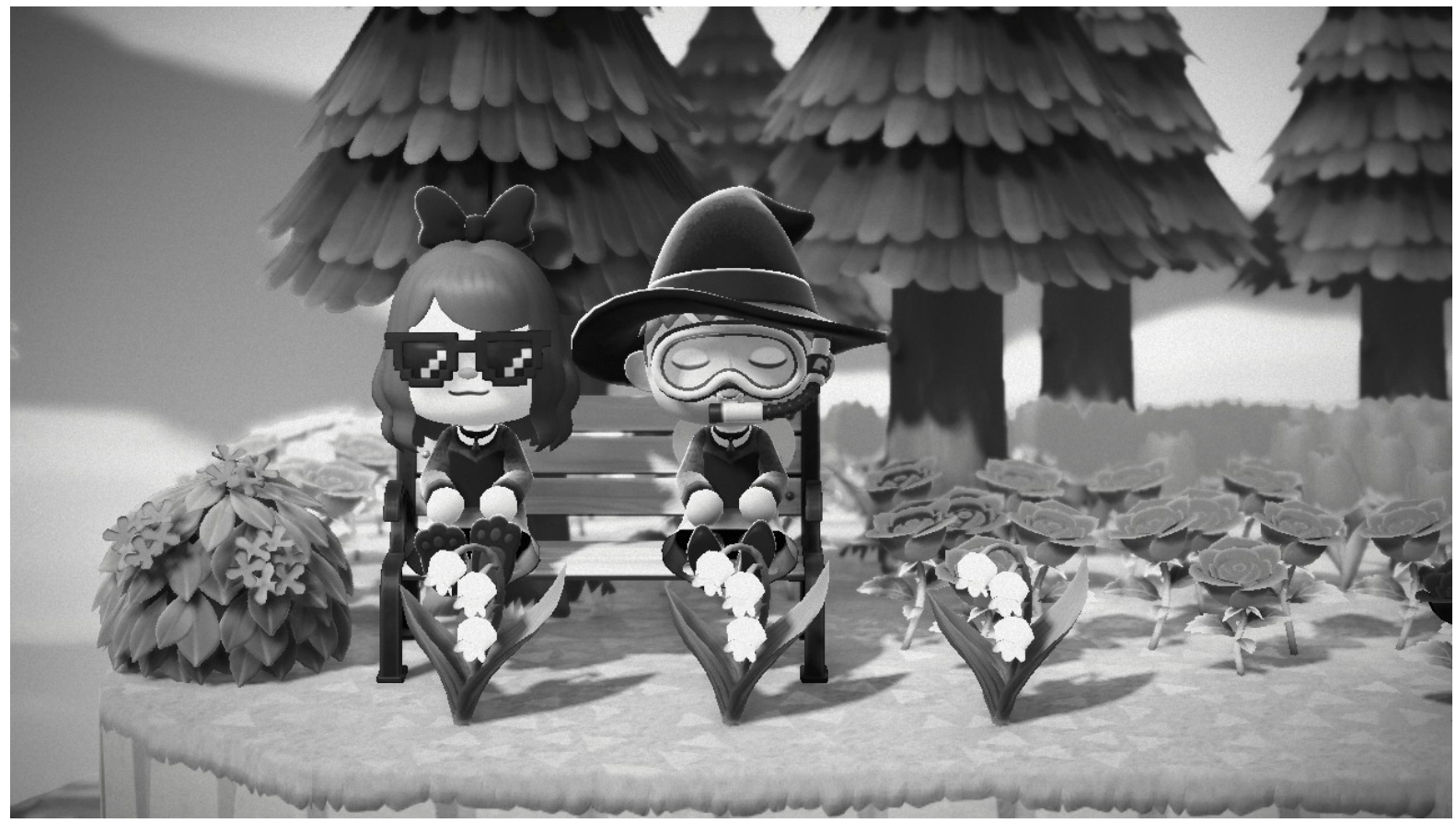

Figure 3: Waiting in Animal Crossing: New Horizons (Nintendo 2020) [Author's screenshot]

$A C N H$ here becomes a subtle reflection on the subject-position of the player, a quiet place to be, as they watch for shooting stars, repeat NPC conversations, wait for the next event, or see the breeze flow through the trees [Fig. 3]. Moreover, the self-propagation of weeds and flowers returns us to issues of agency in a game of minimal demands - a game of waiting, walking and reading. This world moves without us, ticking slowly with its internal clock-where does this leave the bored player? Keogh has keenly contested the idea that videogames are necessarily interactive media, critiquing Game Studies' focus on action, and noting the frequency of waiting and observing narrative cutscenes, extended animation sequences and even cautious hiding in agonistic games (2019, 976-7). Even more radically, Fizek and Gekker have drawn on Pfaller and Žižeks' concept of interpassivity to argue that in some genres, players delegate their enjoyment (Fizek 2018b), and even that players can resist playbour by rejecting interactivity (Gekker 2018). Through their work we can see the condition of 'interpassivity' present in kinds of distracted and bored player, building on Pfaller's definition of the 'antiideological' refusal of interactivity: 'the pleasure in letting others [here the game] consume (instead of work) in one's place' $(2017,1)$, allowing us to 'opt out' of playbour and, as Žižek has it, use digital space to 'gain a minimum of distance' toward our fantasies by externalising them $(1998,511)$. Much as recording television might obviate the need to watch it, or a laughtrack might laugh for us, the automatic perambulation of our villagers and the self-perpetuation of our in-game plants might 'enjoy' for us through an interpassive relationship: 'interpassivity is as much about ritual and habit as it is about actual use' (Gekker 2018, 224).

Through interpassivity, players are not dupes believing consciously that a game can play itself for us, but rather we attribute this belief to a non-existent naive other, creating what Pfaller calls an 'illusion without a subject' that configures a game as a self-fulfilling object that can enjoy on our behalf $(2017,59)$. In $A C N H$ we live in hope that our villagers' perennial happiness will rub off on us, that their naive joy is contagious, and even if we don't believe it, it does. From this strange disposition comes powerful and ambivalent affordances which echo boredom's dispassionate absorption and subversive rejection of anxious engagement: 
'interpassivity attempts to embed passivity within the interactive relation, which may be interpreted both as loyalty to the system, and as a form of resistance' (Van Oenen 2008, 15).

Moreover, we might understand interpassive $A C N H$ as a means of externalising and resisting another illusion without a subject: our fantasy of pre-lockdown life. It mediates the everlockdown anxiety we find hard to pin-down in times of COVID - an anxiety that stems from a denial. As Žižek argues, for all that we might be cynically aware of our alienated existence under capitalism, we continue as if we are not: 'the emperor is naked and the media trumpet forth this fact, yet nobody seems really to mind - that is, people continue to act as if the emperor is not naked' (Žižek 1999, 18). No one believes that our lives are great under capitalism and that nothing is wrong with neoliberal society, unless we all do. We outsourced that belief to a naive other and continued our lives as if nothing were amiss until the pandemic broke our illusion in ways we struggle to process. As Bogost has it, no-one would believe we desire boring capitalism, unless we all do (2020). But while Bogost comes close to the displacement at work here, the affective boredom and passivity of play in $A C N H$ is not a satisfaction with moderated capitalism, but a denial of being moved by it. Enjoying $A C N H$ interpassively lets us opt out of the ever-lockdown, letting our splendid island isolation exist as a ritual of boring plenitude in which to wait with our affects. Our bored interpassivity thus defends us against Fisher's anxious, distracted modernity, Wark's gamespace and McCormick's 'indefinite liminality': the burden of leisure and labour in the ever-lockdown. This isn't a simple escape from pandemic reality, but a game that facilitates a complex and subtle affective response, and resistance, to longer-term conditions of alienation and playbour. Rather than a retreat, $A C N H$ is a 'place' to dwell on the horizon of everyday entanglements in ever-lockdown.

\section{Staying in Place}

As the player sits down and waits for $A C N H$ 's wandering musician to conclude their week, and this analysis reaches its own end, the player and the reader are still pacing back-and-forth through the weeds. $A C N H$ offers no grand final reckoning, but the ambivalently pleasing horizon of many more sunrises and sunsets to come. In the words of one player: 'When times are so dark, people are just looking for something that's not necessarily going to fix everything but to just make things a bit better, temporarily' (Jess 2020 cited Chalk \& Powell 2020). As we've seen, discourse on videogames can tend to treat them as modernist utopian tools of progressive futures, or postmodern virtual conditions of escape, but $A C N H$ is no capitalist dystopia, nor is it a post-capitalist utopia - it's a place to dwell in. Our island is not so much a terrain to exploit as a place to live, with all life's ambivalences, fulfilling a spatial function of games whereby: 'The individual player can experience the game space as a place for dwelling rather than merely a territory' (Nitsche 2008, 193).

To conclude I would like to draw on Olwig's thoughts on place and modernity - that we should move beyond modernism's utopianism and postmodernism's dystopianism to a 'topianism' (which is to say a sense of place) that realises the need to create places that can be lived in (2002) — dwelling, walking and waiting in the landscape are the summation of $A C N H$ 's quiet, topian radicalism. This game, with its messy, boring, calming compromises is not then an object set in opposition to the world, but in Ingold's sense a 'thing,' 'a place where several goings on become entwined' $(2010,4)$. And much as Solnit reflects: 
'When you give yourself to places, they give you yourself back; the more one comes to know them, the more one seeds them with the invisible crop of memories and associations that will be waiting for you when you come back, while new places offer up new thoughts, new possibilities.' (Solnit 2002, 22)

The looping world of Animal Crossing is not an escape from our world, but an entanglement with continuities and the problematic, gradual creep of our neoliberal ever-lockdownenabling an interpassive response to our anxiety in an ever-lockdown age that accentuates longer trends of abstracted life and the penetration of work into domestic play. Rather than offering us direct alternatives to, or reifications of, ever-lockdown, $A C N H$ allows us to walk, wait and reflect on subtle affects and to grow in place with our plants. What this game taps into is not a fear of radical changes in work and leisure in a time of pandemic, but a displaced awareness of the long journey to where we are now, exorcising our anxieties about the progression of neoliberalism. The first affective shift towards a better future, this is not a utopia nor a dystopia but somewhere off the beaten path with the horizon always in our eye-line. In a world that disturbs and disquiets, $A C N H$ is not a retreat, but a means of staying in place.

\section{References}

Anable, A. (2018) Playing with Feelings: video games and affect. Minneapolis: University of Minnesota Press

Batchelor, J. (2020) 'Animal Crossing is now the best-selling Switch game of all time in Japan.' Gamesindustry. biz, May $13^{\text {th }}$ URL:

https://www.gamesindustry.biz/articles/2020-05-13-animal-crossing-new-horizonshas-become-the-best-selling-switch-game-of-all-time-in-japan [Accessed 10/10/2020]

Berlant, L. (2011) Cruel Optimism, Durham: Duke University Press.

Boellstorff, T., Nardi, B., Pearce, C., and Taylor, T. L. (2013) Ethnography and Virtual Worlds: A Handbook of Method. Princeton: Princeton University Press.

Bogost, I. (2012) Alien phenomenology, or, What it's like to be a Thing. Minneapolis: University of Minnesota Press.

Bogost, I. (2007) Persuasive Games. Cambridge: MIT Press.

Bogost, I. (2020) 'The Quiet Revolution of Animal Crossing' The Atlantic. April $15^{\text {th }}$. URL: [https://www.theatlantic.com/family/archive/2020/04/animal-crossing-isntescapist-its-political/610012/ [Accessed 23/06/2020]

Bowman, D. (2019) 'Domesticating the First-Person Shooter: The Emergent Challenge of Gone Home's Homely Chronotope.'Press Start. 5:2. URL: https://core.ac.uk/download/pdf/227108711.pdf 
Bruno, F. (2020) 'Panel Paper: Digital Surveillance and Hyperconnected Pandemic,' LOATHING: Digital Tensions, Fragmentations and Polarisations (King's College London, June 2020).

Carpenter, N. (2020) 'I spent a month away from Animal Crossing and now everything is different.' Polygon. March $26^{\text {th }}$. URL:

https://www.polygon.com/2020/7/2/21310617/animal-crossing-new-horizonsabanoned-island-summer-update [Accessed 22-10-20]

Chalk, W. \& Powell, S. (2020) 'Animal Crossing: Why people play a game about 'meaningless tasks." BBC, April 6" ${ }^{\text {th }}$. URL: https://www.bbc.co.uk/news/newsbeat52135528 [Accessed 10/10/2020]

Chang, A. (2019) 'Corridors: Engaging Multispecies Entanglements through Infrastructural Play,' Resilience: A Journal of the Environmental Humanities, 7:1, Imagining Alternatives (Winter), pp. 68-86

Chery, S. (2020) 'Animal Crossing Game Helps Cure Quarantine Boredom, Anxiety During Pandemic.' WUFT, May $14^{\text {th }}$. URL:

https://www.wuft.org/news/2020/05/14/animal-crossing-game-helps-cure-quarantineboredom-anxiety-during-pandemic/ [Accessed 10/10/2020]

Chess, S. (2017) Ready Player Two. Minneapolis: University of Minnesota Press.

Chmielewski, A. (2020) 'Abstract Society in the Time of Plague.' Philosophy of the social sciences, 50:4, pp.366-380.

Dartnell, L. (2020) 'The Covid-19 changes that could last long-term.' BBC Future, June 30 th URL: https://www.bbc.com/future/article/20200629-which-lockdownchanges-are-here-to-stay [Accessed 10/10/2020]

Duffy, M.E., Twenge, J.M., Joiner, T.E. (2019) 'Trends in Mood and Anxiety Symptoms and Suicide-Related Outcomes Among U.S. Undergraduates, 2007-2018: Evidence From Two National Surveys.' J Adolesc Health. 65:5. pp. 590-598.

Dyer-Witheford, N. \& de Peuter, G. (2009) Games of Empire, Minneapolis: University of Minnesota Press.

Fisher, M. (2016) 'No One is Bored, Everything is Boring,' in M., Ambrose, D. \& Reynolds, S., (eds). K-punk : the collected and unpublished writings of Mark Fisher (2004-2016), London, UK: Repeater.

Fizek. S. (2018a) 'Automated State of Play: Rethinking anthropocentric Rules of the Game.' Digital Culture \& Society 4:1, pp. 201-214

Fizek, S. (2018b) 'Interpassivity and the joy of delegated play in idle games', Transactions of the Digital Games Research Association, 3, https://doi.org/10.26503/todigra.v3i3.81. [Accessed 12/07/2018]

Fleury, J., Hartzheim, B.H. \& Mamber, S. (2020) The Franchise Era: managing media in the digital economy, Edinburgh: Edinburgh University Press. 
Frushtick, R. (2020) 'Animal Crossing: New Horizons is a much-needed escape from everything,' Polygon. :

https://www.polygon.com/reviews/2020/3/16/21178911/animal-crossing-newhorizons-review-nintendo-switch [Accessed 26/06/2020]

Gekker, A. (2018) 'Let's not play: Interpassivity as resistance in 'Let's Play' videos.' Journal of gaming \& virtual worlds, 10:3, pp.219-242

Gardiner, M.E. \& Haladyn, J.J. (2017) Boredom Studies Reader: frameworks and perspectives. New York: Routledge.

Graeber, D. (2018) Bullshit Jobs: a theory, UK: Allen Lane.

Harari, Y. N. (2020) 'Yuval Noah Harari: the world after coronavirus.' Financial Times, March 20th. URL: https://www.ft.com/content/19d90308-6858-11ea-a3c91 fe6fedcca75 [Accessed 27/06/2020]

Harman, G. (2018) Object-oriented ontology: a new theory of everything, UK: Pelican Haraway D. (1985) 'Manifesto for cyborgs: science, technology, and socialist feminism in the 1980s.' Socialist Review, no. 80 pp.65-108

Huizinga, J. (1998) Homo Ludens: a study of the play-element in culture, London: Routledge.

Ingold, T. (2010) 'Bringing Things to Life: Creative Entanglements in a World of Materials.' Realities Working Papers, no. 15 pp.1-14.

Isbister, K. (2016) How Games Move Us: emotion by design, Cambridge, Massachusetts: The MIT Press.

Jenkins, H. (2007) 'Anatomy of a Game Secret (Part Two): Animal Crossing.' [Blog] Confessions of an Aca-fan. URL:

http://henryjenkins.org/blog/2007/05/anatomy_of_a_game_secret_part.html [Accessed 20/10/20]

Jenkins, H. (2006) '"COMPLETE FREEDOM OF MOVEMENT": VIDEO GAMES AS GENDERED PLAY SPACES.' In Salen, K.S. \& Zimmerman, E., (eds) The Game Design Reader: a rules of play anthology, Cambridge, Mass.: MIT Press.

Johnson J. \& Lipscomb J. (2006) 'Long working hours, occupational health and the changing nature of work organization.' Am J Ind Med. 49:11. pp. 921-9.

Juul, J., (2009) A Casual Revolution: reinventing video games and their players, Cambridge, Massachusetts: MIT Press.

Kang, Myounggu et al., (2020) 'COVID-19 impact on city and region: what's next after lockdown?' International Journal of Urban Sciences, 24(3), pp.297-315.

Keogh, B. (2018) A Play of Bodies: a phenomenology of videogame experience. Cambridge, Massachusetts: The MIT Press. 
Keogh, B. (2019) 'Instantaneously punctuated picture-music: Re-evaluating videogame expression through Pilgrim in the Microworld.' Convergence: The International Journal of Research into New Media Technologies, 25:5 970-984

Keogh, B. \& Richardson, I. (2018) 'Waiting to Play: The labour of background games.' European journal of Cultural Studies. 21:1. pp.13-25

Kingwell, M. (2019) Wish I Were Here: Boredom and the Interface. Chicago: McGillQueen's University Press.

Krastev, I. (2020) Est-ce déjà demain? Le monde paradoxal de l'après-Covid-19. Paris: Premier Parallèle.

Kücklich, J. (2005) 'Precarious Playbour: Modders and the Digital Games Industry.' Fibre Culture, 5. URL: http://five.fibreculturejournal.org/fcj-025-precarious-playbourmodders-and-the-digital-games-industry/

Liffreing, I. (2020) 'BRANDS HOST VIRTUAL EVENTS IN ANIMAL CROSSING.' Advertising Age. 91:12. URL:

https://search.proquest.com/docview/2409326803?accountid=10673

MacDonald, K. (2020) 'It's uniting people': why 11 million are playing Animal Crossing: New Horizons,' The Guardian, May $13^{\text {th }}$. URL:

https://www.theguardian.com/games/2020/may/13/animal-crossing-new-horizonsnintendo-game-coronavirus [Accessed: 29/06/2020]

Mabey, R. (2010) Weeds: In Defense of Nature's Most Unloved Plants. New York: Harper Collins.

McCormick, L. (2020) 'Marking time in lockdown: heroization and ritualization in the UK during the coronavirus pandemic.' Am J Cult Sociol. https://doi.org/10.1057/s41290-020-00117-8

Meyrowitz, J. (1987) No Sense of Place The Impact of Electronic Media on Social Behavior. New York: Oxford University Press.

Moore, P. Upchurch, M., Whittaker X. (2018) 'Humans and Machines at Work: Monitoring, Surveillance and Automation in Contemporary Capitalism' Phoebe V. Moore, Martin Upchurch and Xanthe Whittaker (eds) Humans and Machines at Work Monitoring, Surveillance and Automation in Contemporary Capitalism. Cham:

Palgrave Macmillan.

Nintendo. (2020) Animal Crossing: New Horizons. Nintendo.

Nitsche, M. (2008) Video Game Spaces: image, play, and structure in 3D game worlds, Cambridge, Mass.: MIT Press.

Olwig, K. (2002) 'Landscape, place, and the state of progress', in R. D. Stack (ed.), Progress: Geographical Essays, Baltimore, MD: Johns Hopkins University Press.

Parrish, A. (2020) 'Let me keep my damn weeds, Animal Crossing.' Kotaku URL: https://kotaku.com/let-me-keep-my-damn-weeds-animal-crossing-1843885508 
Pfaller, R. (2017) Interpassivity: The aesthetics of delegated enjoyment, Edinburgh: Edinburgh University Press.

Perron, B \& Schröter, F. (eds.) (2016) Video Games and the Mind: essays on cognition, affect and emotion. McFarland \& Company Inc.: Jefferson.

Politico Magazine, (2020) 'Coronavirus Will Change the World Permanently. Here's How.' Politico, March 19th. URL:

https://www.politico.com/news/magazine/2020/03/19/coronavirus-effect-economylife-society-analysis-covid-135579\#community [Accessed 11/10/2020]

Schmalzer, M. D. (2020) 'Janky Controls and Embodied Play: Disrupting the Cybernetic Gameplay Circuit.' Game Studies 20:3.

Schwab, K. (2016) 'The Fourth Industrial Revolution: What it Means, How to Respond.' World Economic Forum. URL:

https://www.weforum.org/agenda/2016/01/the-fourth-industrial-revolution-what-itmeans-and-how-to-respond/. [Accessed 10/09/2020]

Scully-Blaker, R. (2019) 'Buying Time: Capitalist Temporalities in Animal Crossing: Pocket Camp.' Loading... 12:20. pp. 90-106

Snickars, P. \& Vonderau, P., (2009) The YouTube reader, Stockholm: National Library of Sweden.

Soderman, B. (2017) 'No Time to Dream: killing Time, Casual Games, and Gender,' in Malkowski, J. \& Russworm, T. M. (eds.). Gaming Representation, Bloomington: Indiana University Press.

Solnit, R. (2002) Wanderlust: a history of walking. London ; New York: Verso.

Stone, K. (2018) 'Time and Reparative Game Design: Queerness, Disability, and Affect.' Game Studies. 18:3.

Svendsen, L.F.H. \& Irons, J. (Trans.), (2005) A Philosophy of Boredom, London: Reaktion.

Taylor, T.L. (2018) Watch Me Play. Princeton University Press, Princeton, New Jersey.

Tisdall, S. (2020) 'Power, equality, nationalism: how the pandemic will reshape the world.' Guardian, March 28 ${ }^{\text {th }}$. URL:

https://www.theguardian.com/world/2020/mar/28/power-equality-nationalism-howthe-pandemic-will-reshape-the-world [Accessed 10/10/2020]

Twenge, J. M \& Joiner, T. E. (2020) 'U.S. Census Bureau-assessed prevalence of anxiety and depressive symptoms in 2019 and during the 2020 COVID-19 pandemic.' Depression and Anxiety, 37:10, pp. 954-956.

Urquhart, E. (2020) 'Animal Crossing: New Horizons Is an Escape Into Comforting Boredom.' Slate. April $7^{\text {th }}$. URL: https://slate.com/culture/2020/04/animal-crossingnew-horizons-coronavirus-boredom.html [Accessed 10/10/2020] 
Van Oenen, G. (2008) 'Interpassivity revisited: A critical and historical reap- praisal of interpassive phenomena', International Journal of Žižek Studies, 2:2, pp 1-16.

Wark, M.K. (2007) Gamer Theory, Cambridge, Mass.: Harvard University Press.

Yeung, J. (2020) 'Animal Crossing' Is on Track to Become Nintendo's Best-Selling Game Ever for the Switch.' Hypebeast, Nov $6^{\text {th }}$. URL:

https://hypebeast.com/2020/11/nintendo-switch-animal-crossing-new-horizons-bestselling-game [Accessed 8/11/2020]

Zhu L. (2020) 'The psychology behind video games during COVID-19 pandemic: A case study of Animal Crossing: New Horizons'. Hum Behav \& Emerg Tech;1-3. URL: https://doi.org/10.1002/hbe2.221

Žižek, S. (1998) 'Cyberspace, or, How to Traverse the Fantasy in the Age of the Retreat of the Big Other.' Public Culture, 10:3, pp.483-513.

Žižek, S. (1999) "The Spectre of Ideology." In Zizek, S. ed. Mapping Ideology. New York: Verso.

Žižek, S. (2020) Pandemic! COVID-19 Shakes the World. Cambridge: Polity.

\section{Biography}

Dr Merlin Seller completed their MA and Mst at St Andrews and Oxford respectively, obtaining their doctoral thesis at the University of East Anglia concerning transmedia and remediating works between film, photography and painting. They are a proudly pansexual/non-binary academic with a background in Art History and Visual Cultural Studies, and teaching experience in game design. They are currently Lecturer in Design and Screen Cultures at the University of Edinburgh, working across Film, Comics, Media and Game Studies. Their present research interests concern Phenomenology, Horror, and the Non-human turn in new media.

E.: merlin.seller@ed.ac.uk 